\title{
New records of Pegantha spp. (Hydrozoa: Narcomedusae) off Northern Brazil
}

\author{
Everton Giachini Tosetto ${ }^{1,3}$, Sigrid Neumann-Leitão ${ }^{1,4}$ \& Miodeli Nogueira Júnior ${ }^{2}$ \\ 1 Universidade Federal de Pernambuco (UFPE), Centro de Tecnologia e Geociências (CTG), Departamento de 0ceanografia (DOCEAN). \\ Recife, PE, Brasil. \\ 2 Universidade Federal da Paraíba (UFPB), Centro de Ciências Exatas e da Natureza (CCEN), Departamento de Sistemática e Ecologia (DSE). \\ João Pessoa, PB, Brasil. ORCID: 0000-0001-5409-8312. E-mail: miodeli@gmail.com \\ 3 ORCID: 0000-0002-4020-0942. E-mail: evertontosetto@hotmail.com (corresponding author). \\ 4 ORCID: 0000-0001-7878-8772. E-mail: sigridnl@uol.com.br
}

\begin{abstract}
Specimens of Pegantha laevis H.B. Bigelow, 1909 and Pegantha triloba Haeckel, 1879 were found in oceanic waters off the northern Brazilian coast. The former species is clearly distinct due to the thickness and shape of peripheral channels, while the latter is recognized mainly due to the exumbrellar furrows and long otoporpae. This study represents the first actual record of P. laevis inside the Brazilian Economic Exclusive zone, since previous reports were far away from the coast, and clarifies the presence of $P$. triloba off Brazil.
\end{abstract}

Key-Words. Jellyfish; Cnidaria; Hydrozoa; Taxonomy; Biodiversity; South Atlantic.

\section{INTRODUCTION}

Holoplanktonic hydromedusae of the family Solmarisidae Haeckel, 1879 is distinguished from other Narcomedusae mainly by the absence of manubrial pouches, thus the periphery of manubrium is circular and unbroken at the same level as the tentacles rise. Two genera are recognized in the family: i) Pegantha Haeckel, 1879, with a peripheral canal system and otoporpae, and gonads forming lobes on the margin of manubrium wall; and ii) Solmaris Haeckel, 1879, without peripheral canal system and otoporpae and with simple annular gonads (Bouillon \& Boero, 2000; Bouillon, et al. 2004, 2006).

Currently there are five valid species of Pegantha, in addition to many doubtful names regarded as "taxon inquirendum" or possible synonymies (Schuchert, 2015). All valid species are widely distributed, mostly in epipelagic oceanic waters (Kramp, 1957, 1961; Bouillon, 1999). At southwestern Atlantic all the five species have been found (Bouillon, 1999), among which Pegantha laevis H.B. Bigelow, 1909 was recorded off Argentina and in oceanic waters $>1,300 \mathrm{~km}$ offshore the Brazilian coast (Kramp, 1957; Genzano et al., 2008). Pegantha triloba Haeckel, 1879 was recorded at Fernando de Noronha archipelago (Vanhöffen, 1913) and offshore North of Brazil (Ranson, 1949; Kramp, 1959b), but its occurrence has been overlooked by Oliveira et al. (2016) in the census of Cnidaria from South America, and thus its distribution became uncertain. Hydromedusae are important predators in marine zooplankton and information on its distribution is essential for understanding species diversity, biogeographic patterns and marine ecosystem functioning. In this study, we report the occurrence of both species on North Brazilian shelf and offshore waters, extending northwards the known distribution of $P$. laevis in the western Atlantic and clarifying the presence of $P$. triloba in Brazilian waters.

\section{MATERIALS AND METHODS}

One specimen of Pegantha laevis and eight specimens of Pegantha triloba were found in superficial plankton samples collected in oceanic waters off the northern coast of Brazil (Table 1) with a David-Hempel catamaran (Hydro-Bios, Kiel, Germany) equipped with two superposed nets, each with a rectangular mouth and 500 $\mu \mathrm{m}$ mesh size. Sub-superficial temperature and salinity was measured with a Seabird SBE 25 Sealogger CTD profiler. Specimens were depos-

Table 1. Pegantha laevis and Pegantha triloba occurrences off northern Brazil. $\mathrm{T}=$ temperature; $S=$ salinity.

\begin{tabular}{lccccc}
\hline & Location & $\begin{array}{c}\text { Number of } \\
\text { specimens }\end{array}$ & $\mathbf{T}\left({ }^{\circ} \mathbf{C}\right)$ & S & $\begin{array}{c}\text { Bottom } \\
\text { depth (m) }\end{array}$ \\
\hline P. laevis & $0.0013^{\circ} \mathrm{N}, 38.0073^{\circ} \mathrm{W}$ & 1 & 27.9 & 36.2 & 4,426 \\
P. triloba & $3.9963^{\circ} \mathrm{N}, 38.0042^{\circ} \mathrm{W}$ & 7 & 28.1 & 36 & 4,208 \\
& $5.9126^{\circ} \mathrm{N}, 49.7035^{\circ} \mathrm{W}$ & 1 & 27.6 & 36.2 & 3,592 \\
\hline
\end{tabular}


ited in the Museu de Oceanografia Prof. Petrônio Alves Coelho from Universidade Federal de Pernambuco. All applicable international, national, and/or institutional guidelines for the care and use of animals were followed by the authors.

\section{RESULTS AND DISCUSSION}

The single Pegantha laevis medusa found was $9 \mathrm{~mm}$ in bell diameter. Umbrella flattened with completely smooth surface (Fig. 1A). The specimen was damaged

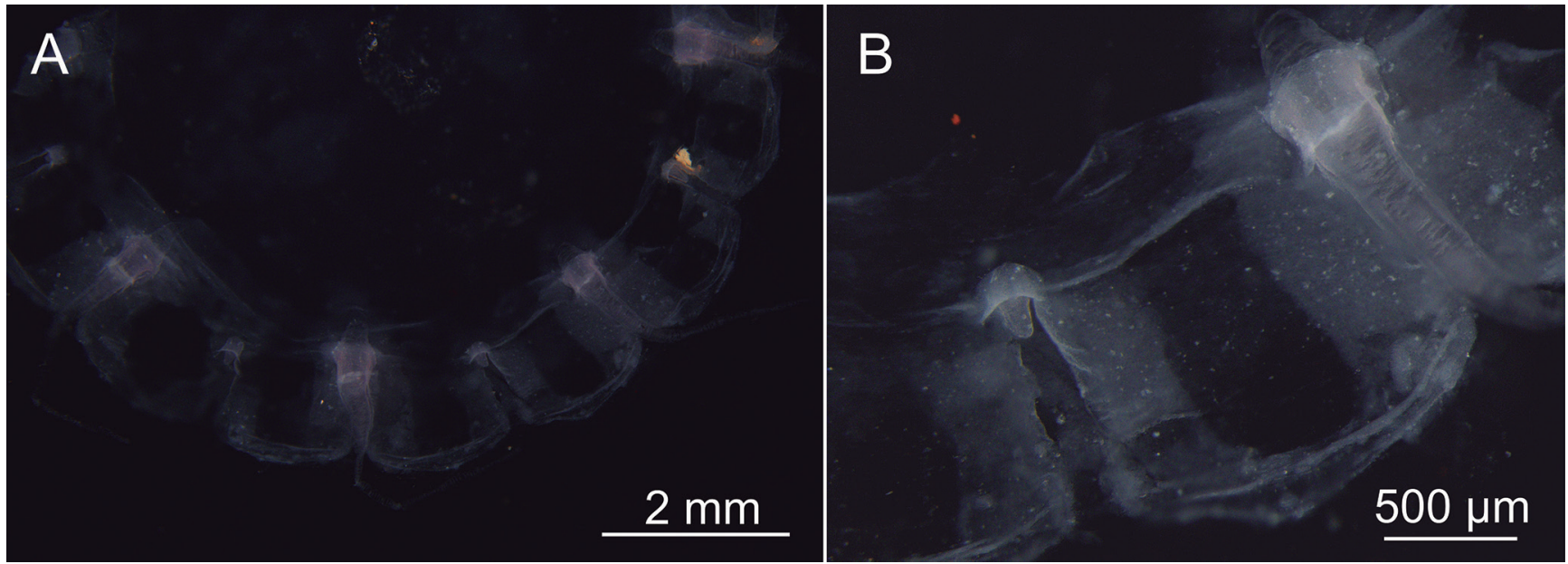

Figure 1. Pegantha laevis medusa from North Brazil. (A) Aboral view. (B) Detail of marginal lappet and peripheral channel.

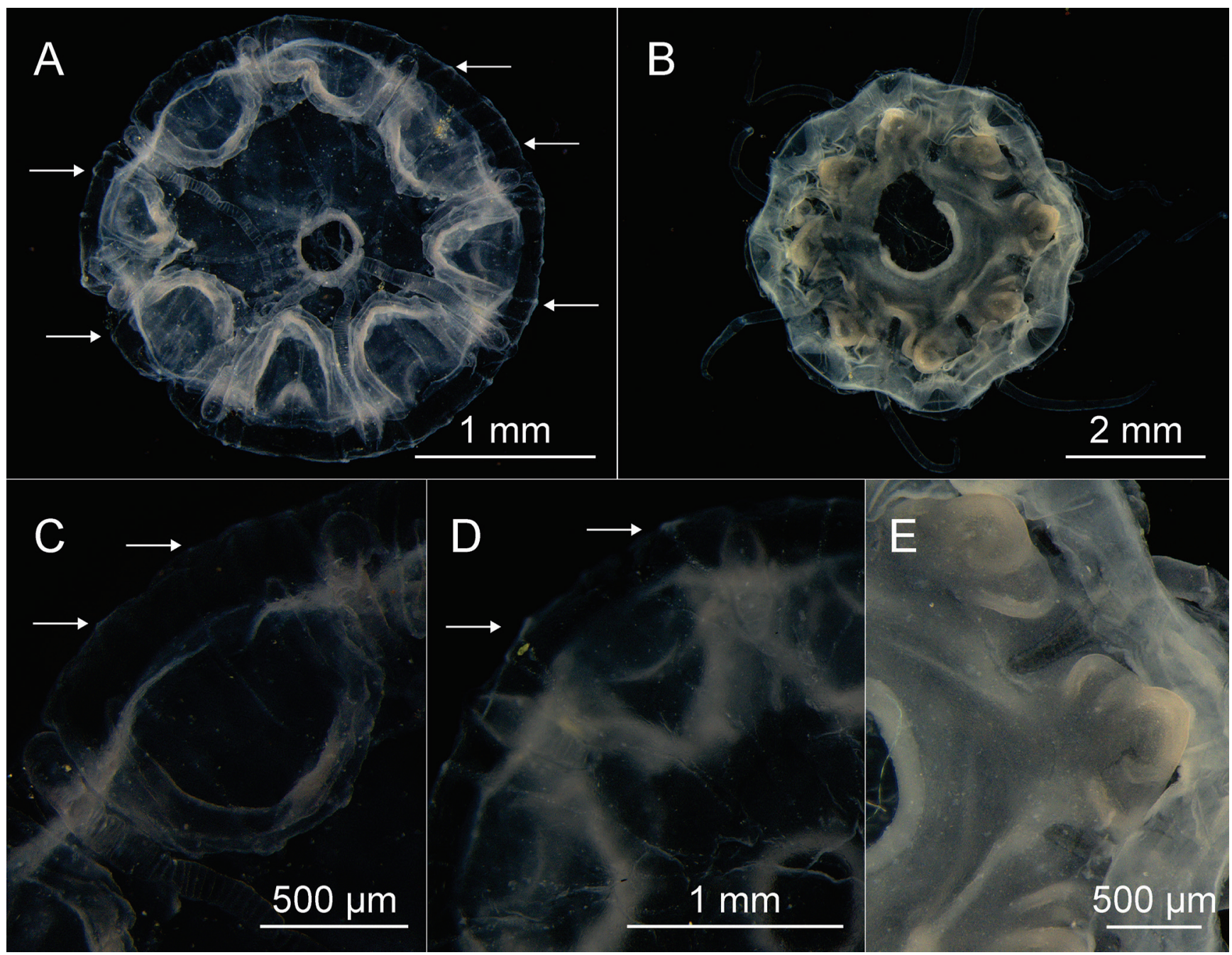

Figure 2. Pegantha triloba medusae from North Brazil. (A and B) Oral view. (C) Detail of marginal lappet and otoporpae. (D) Aboral view showing furrows and ridges on exumbrella. (E) Detail of tri-lobed gonads. Arrows indicate some otoporpae. 
and $c a .1 / 5$ of the margin was missing, and about 16 square marginal lappets were estimated. Peripheral canals quadrate, very broad mainly in the sides which represent 1/3-1/4 of the total lappet width and do not tapering (Fig. 1B). Only remnants of short otoporpae present, with nearly the same length of the peripheral canal width. Gonads absent.

A total of eight individuals of Pegantha triloba were analyzed, ranging from 1.5 to $4.6 \mathrm{~mm}$ in bell diameter (Fig. 2A). Seven medusae presented eight marginal lappets and one medusa had nine lappets. Peripheral canals thin, more or less triangular with rounded or pointed margins (Fig. 2B). Typically, three long otoporpae in the smaller medusae and five in the two larger ones, reaching almost the middle of the central disk and tapering upwards; exumbrella with furrows from the base of the tentacles to almost the apex, leaving the central disk smooth (Figs. 2A, B). The largest specimen presented gonads with three lobes (Figs. 2B, D), except one of the gonads with a single lobe.

Species of the genus Pegantha are mostly characterized by the width and/or shape of the peripheral canals, the size of the otoporpae and the presence/absence of exumbrellar furrows (Kramp, 1957, 1959b, 1961, 1965, 1968; Pagès et al., 1992; Bouillon, 1999; Bouillon et al., 2004). The number of gonadal lobes has also been used by earlier researchers (e.g., Haeckel 1879), but this has been long shown to be highly variable and not accurate to distinguish species (e.g., Bigelow, 1909; Kramp, 1961).

Pegantha triloba is easily distinguished from the remaining species by the exumbrella with furrows. This character, along with the long otoporpae and relatively thin peripheral canal system (Fig. 2B), confirm the present identification (e.g., Bigelow, 1909; Kramp, 1957, 1959b, 1961; Bouillon, 1999). Bigelow (1909) described the otoporpae reaching the level of the base of the tentacles, however latter authors indicate the otoporpae may be considerably longer than the lappet, reaching the apex of the exumbrella (Kramp, 1957) likewise the present material (Fig. 2D). The observed medusae have 8-9 marginal lappets and tentacles, less than the 12-16 typically reported for this species. This may be attributed to the small size of our specimens (Xu \& Wu, 1998), in spite the fact that one of them already had gonads. Although medusae as small as 5-7 mm have 12-14 lappets (Kramp, 1957), our specimens are smaller (1.5 to $4.6 \mathrm{~mm}$ ) and in accordance with the medusa reported by Bigelow (1909) (with $2.5 \mathrm{~mm}$ in diameter and 7 lappets). The smaller number of otoporpae (3-5 per lappet) observed in the present specimens is also probably related to the small size of the medusae sampled here (see Bigelow, 1909: 88).

Among Pegantha species with smooth exumbrella, P. laevis differs from Pegantha clara R.P. Bigelow, 1909 and Pegantha rubiginosa (Kölliker, 1853) in the thickness of the peripheral canals. Pegantha martagon Haeckel, 1879 has also thick peripheral canals, however those from $P$. laevis are even thicker, being almost as wide as the space between them (Kramp, 1957; Fig. 1B). Also, the peripheral canals of $P$. martagon taper towards the margin (Bigelow, 1909; Kramp, 1957, 1961), while the same is not true for P. laevis (Fig. 1B). These differences in the

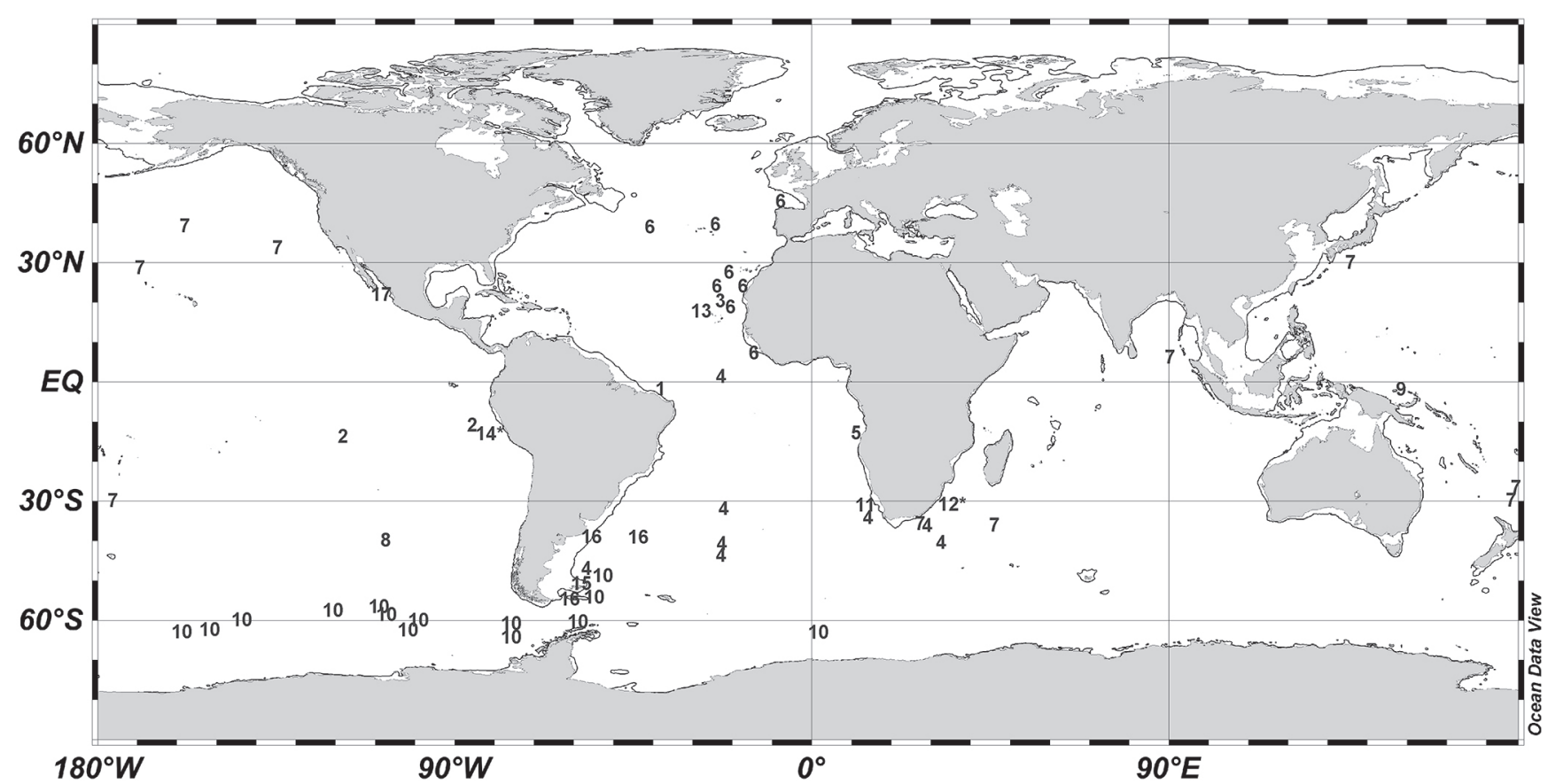

Figure 3. Global distribution of the narcomedusa Pegantha laevis based on this study and literature records. The dashed line shows the $250 \mathrm{~m}$ isobath, roughly corresponding to the shelf break (generated using 0cean Data View software; Schlitzer, 2007). Data Source: $1=$ this study; $2=$ Bigelow, 1909; $3=$ Kramp, 1955; $4=$ Kramp, 1957; $5=$ Kramp, 1959a; $6=$ Kramp, 1959b; $7=$ Kramp, 1965; 8 = Fagetti, 1973; $9=$ Bouillon et al., 1986; Bouillon, 1978; $10=$ Navas-Pereira \& Vannucci, 1990; 11 = Pagès et al., 1992; 12 = Buecher et al., 2005; 13 = León et al., 2005; 14 = Ayón et al., 2008; 15 = Genzano et al., 2008; 16= Rodriguez, 2012; $17=$ Gasca \& Browne, 2017. 
peripheral canal system are robust and may help even the identification of badly preserved specimens (Kramp, 1957). In addition, P. martagon has a vaulted umbrella, while in $P$. laevis the umbrella is flatter and lenticular (Bouillon, 1999).

Although P. laevis is not a common species (Kramp, $1959 b, 1968)$, it is widely distributed in tropical, temperate and even Antarctic (temperatures down to $0.2^{\circ} \mathrm{C}$; Navas-Pereira \&Vannucci, 1990) regions of the three large oceans, but mostly in the Atlantic and Pacific (Fig. 3). Its known distribution is somewhat skewed southwards, with current records not surpassing $50^{\circ} \mathrm{N}$, but reaching nearly $70^{\circ} \mathrm{S}$ (Fig. 3). In South Atlantic waters, the occurrence of this species was recorded off the African and Argentinean coast and in the center of the Atlantic at tropical, temperate and polar latitudes (Fig. 3). Recently, Oliveira et al. (2016) considered this medusa as integrating the Brazilian fauna based on Kramp's (1957) record at $31.27^{\circ} \mathrm{S}, 29.94^{\circ} \mathrm{W}$ (number 4 in Fig. 3). However, this location is $>1,300 \mathrm{~km}$ offshore, in the center of Atlantic Ocean (Fig. 3), and far outside the economic exclusive zone and Brazilian waters. Thus, the present study represents the first actual record of this species off Brazil.

Pegantha triloba is widely distributed in oceanic waters of the Atlantic, Indian and Pacific Oceans, mainly in warm latitudes between ca. $30^{\circ} \mathrm{N}$ and $30^{\circ} \mathrm{S}$ (Fig. 4). Outside this latitudinal range, $P$. triloba has been recorded at northwest of South Georgia $\left(48^{\circ} \mathrm{S}\right)$, in the Mediterranean and in the Southern Ocean, a single record on each locality (respectively numbers 5, 4 and 35 in Fig. 4). The two latter records may be misidentifications (Kramp, 1959b, 1965). In the South Atlantic, the species was recorded off the African coast and in several oceanic localities between Africa and South America (Fig. 4). Although there were some previous records of this species on Brazilian waters (Ranson, 1949; Kramp, 1959b), these occurrences were overlooked in a recent review (Oliveira et al., 2016), perhaps because they were reported only as "Atlantic" or "Equatorial Atlantic". Thus, this study highlights the presence of $P$. triloba in oceanic waters offshore northern Brazilian coast. While specimens collected in this study were in the subsurface, this species has extensive vertical distribution from surface to strata as deep as 5,000 m (Bigelow, 1909; Kramp, 1959b, 1965).

Holoplanktonic animals such as Pegantha species usually present a wide distribution in the oceans, being dispersed by large-scale processes such as global circulation (Boltovskoy et al., 2003). Furthermore, many Narcomedusae early life stages are parasitic ( $\mathrm{Xu} \& \mathrm{Wu}$, 1998; Osborn, 2000), and movement and migration of their hosts can also contribute to the wide distribution of P. laevis and P. triloba (Figs. 3, 4).

The waters off the northern Brazilian coast are amongst the least studied regarding zooplankton in general (Lopes, 2007) and medusae in particular (Oliveira et al., 2016), leaving a gap in the understanding of spe-

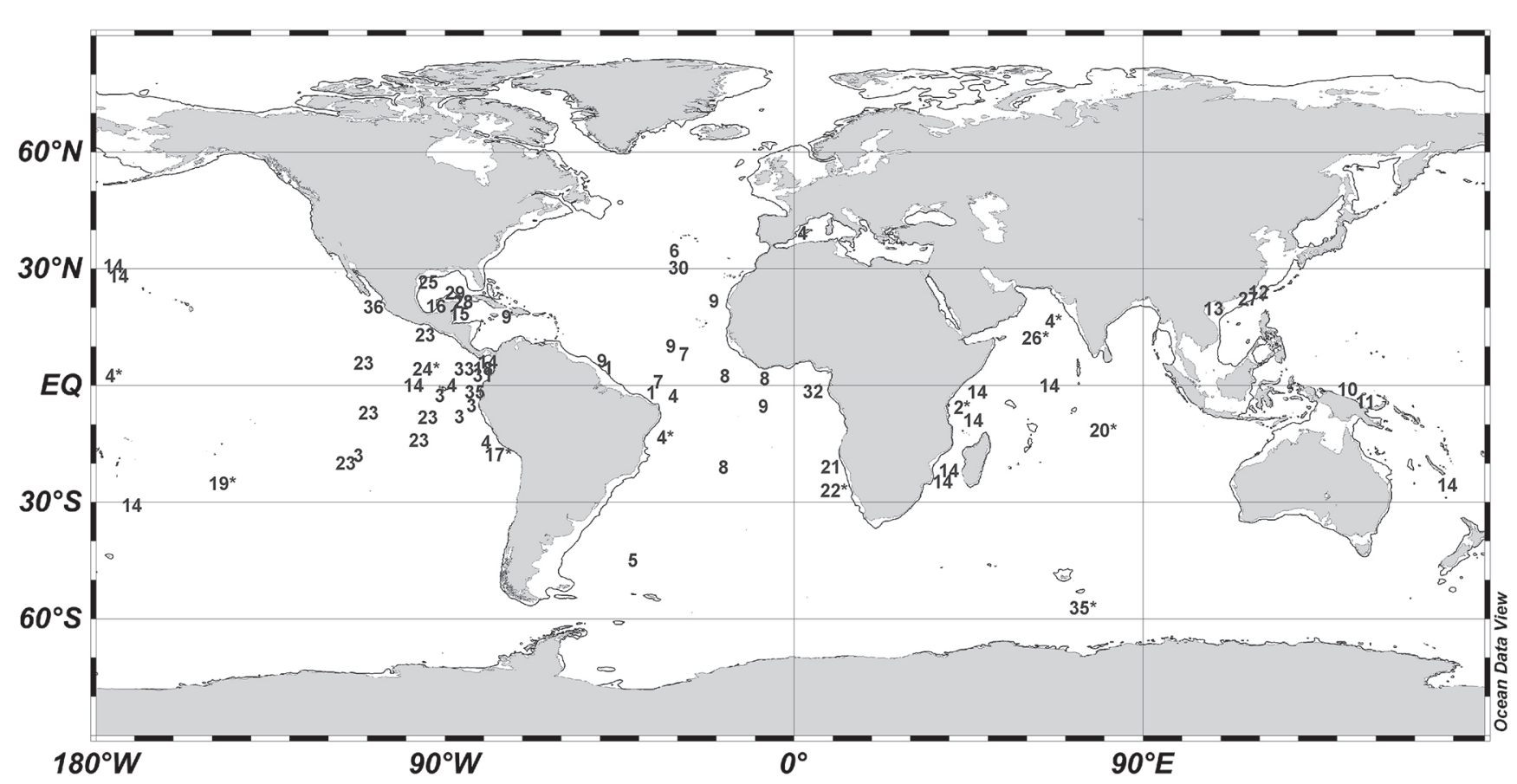

Figure 4. Global distribution of the narcomedusa Pegantha triloba based on this study and literature records. The dashed line shows the $250 \mathrm{~m}$ isobath, roughly corresponding to the shelf break (generated using Ocean Data View software; Schlitzer, 2007). Data Source: $1=$ this study; $2=$ Haeckel, 1879; $3=$ Bigelow, 1909; 4 = Vanhöffen, 1913; 5 = Kramp, 1948a; 6 = Kramp, 1948b apud Kramp, 1961; 7 = Ranson, 1949; 8 = Kramp, 1957; 9 = Kramp, 1959b; $10=$ Bouillon et al., 1988; 11 = Bouillon et al., 1986; 12 = Chang, 2008; 13 = Du et al., 2012; $14=$ Kramp, 1965; 15 = Larson, 1982; 16 = Loman-Ramos et al., $2007 ; 17=$ Ayón et al., 2008 ; $18=$ Baldrich \& López, 2010; 19 = Navas-Pereira \& Vannucci, 1990; 20 = Navas-Pereira \& Vannucci, 1991; 21 = Pagès, 1992; 22 = Pagès et al., 1992; 23 = SeguraPuertas, 1984; 24 = Segura-Puertas, 1991; 25 = Suárez-Morales et al., 2002; 26 = Vannucci \& Navas, 1973; 27 = Xu \& Wu, 1998; 28 = Suárez-Morales et al., 1999; $29=$ Segura-Puertas, 1992; 30 = Bleeker \& Van Der Spoel, 1988; $31=$ Chaparro \& Peralta, 2013; 32 = Repelin, 1965; 33 = Chaparro, 2007; 34= Muñoz-Pozo, 2015; 35 = Vanhöffen, 1912 apud Kramp, 1961; 36 = Fernández-Álamo, 2002. 
cies diversity and biogeographical patterns. Particularly considering the Amazon River plume as a potential barrier for marine organisms (e.g., Rocha, 2003), and the potential high diversity of this understudied tropical and highly productive ecosystem. These aspects emphasize the need of comprehensive surveys in the area and faunistic studies such as the present one.

\section{ACKNOWLEDGEMENTS}

We thank the support of Brazilian National Institute of Science and Technology for Tropical Marine Environments - INCT AmbTropic (CNPq/FAPESB grants 565054/2010-4 and 8936/2011), Brazilian Research Network on Global Climate Change - Rede CLIMA (FINEP grant 01.13.0353-00) and European Integrated CARBOCHANGE (FP7 264879). Everton Giachini Tosetto was supported by CNPq (grant 140897/2017-8). And also to all the boarded scientific team of Camadas Finas III and Amadeus II research project.

Conflict of Interest: The authors declare that they have no conflict of interest.

\section{REFERENCES}

Ayón, P.; Criales-Hernandez, M.I.; Schwamborn, R. \& Hirche, H.J. 2008. Zooplankton research off Peru: A review. Progress in Oceanography, 79(2-4): 238-255.

Baldrich, A.M. \& López, R.H. 2010. Hidromedusas mesozooplanctónicas del océano Pacífico colombiano. Biota Colombiana, 11(1/2): 3-11.

Bigelow, H.B. 1909. Report of the Scientific Expedition to the Eastern Tropical Pacific US Fish. comm. St. "Albatross" 1904-1905. XVI Medusae. Memoirs of the Museum of Comparative Zoology at Harvard, 37: 301-320.

Bleeker, J. \& Van Der Spoel, S. 1988. Medusae of the Amsterdam Mid North Atlantic Plankton Expeditions (1980-1983) with description of two new species. Bijdragen tot de Dierkunde, 58(2): 227-258.

Boltovskoy, D.; Correa, N. \& Boltovskoy, A. 2003. Marine zooplanktonic diversity: a view from the South Atlantic. Oceanologica Acta, 25: 271-278.

Bouillon, J. 1978. Hydroméduses de la mer de Bismarck. (Papouasie NouvelleGuinée). Partie II: Limnomedusa, Narcomedusa, Trachymedusa et Laingiomedusa (sous-classe nov.). Cahiers de Biologie Marine, 19: 473-483.

Bouillon, J. 1999. Hydromedusae. In: Boltovoskoy, D. South Atlantic zooplankton. Leiden, Backhuys Publishers. p. 424-512.

Bouillon, J. \& Boero, F. 2000. Synopsis of the families and genera of the Hydromedusae of the world, with a list of the worldwide species. Thalassia Salentina, 24: 47-296.

Bouillon, J.; Claereboudt, M. \& Seghers, G. 1986. Hydroméduses de la baie de Hansa (Mer de Bismarck; Papouasie; Nouvelle-Guinée). Répartition, conditions climatiques et hydrologiques. Indo-Malayan Zoology, 3(2): 105-152.

Bouillon, J.; Gravili, C.; Pagès, F.; Gili, J.M. \& Boero, F. 2006. An introduction to Hydrozoa. Mémoires du Muséum national d'Histoire naturelle, 194: 1-591.

Bouillon, J.; Medel, M.D.; Pagès, F.; Gili, J.M.; Boero, F. \& Gravili, C. 2004. Fauna of the Mediterranean hydrozoa. Scientia Marina, 68(suppl. 2): 1-454.

Bouillon, J.; Seghers, G. \& Boero, F. 1988. Notes additionnelles sur les méduses de Papouasie Nouvelle-Guinée (Hydrozoa, Cnidaria). III. Indo-Malayan Zoology, 5: 225-253.
Buecher, E.; Goy, J. \& Gibbons, M.J. 2005. Hydromedusae of the Agulhas current. African Invertebrates, 46(1): 27-69.

Chang, W. 2008. Spatiotemporal distribution of hydromedusae in relation to hydrography in the waters surrounding Taiwan. Ph.D. Thesis. National Sun Yat-Sen University, Taiwan.

Chaparro, A.M.B. 2007. Hidromedusas del Pacífico Colombiano durante los cruceros 2001-2004 del estudio regional del fenómeno El Niño. B.S. thesis. Universidad de Bogotá, Bogotá.

Chaparro, A.M.B. \& Peralta, R.H.L. 2013. Hidromedusas del Pacífico Colombiano: Aspectos Básicos de su Dinámica Ecológica. Revista Facultad de Ciencias Básicas, 9(1): 108-131.

Du, F.Y.; Xu, Z.Z.; Huang, J.Q. \& Guo, D.H. 2012. Studies on the medusae (Cnidaria) from the Beibu Gulf in the Northern South China Sea, with description of three new species. Acta Zootaxonomica Sinica, 37(3): 506-519.

Fagetti, E. 1973. Medusas de aguas chilenas. Revista de Biología Marina, Valparaíso, 15(1): 31-75.

Fernández-Álamo, M.A. 2002. Sifonoforos, medusas, poliquetos y quetognatos pelágicos de Bahía de Banderas, Jalisco-Nayarit. Informe final del proyecto S147. CONABI0, Mexico City.

Gasca, R. \& Browne, W.E. 2017. Symbiotic associations of crustaceans and a pycnogonid with gelatinous zooplankton in the Gulf of California. Marine Biodiversity.

Genzano, G.; Mianzan, H.W. \& Bouillon, J. 2008. Hydromedusae (Cnidaria: Hydrozoa) from the temperate southwestern Atlantic Ocean: a review. Zootaxa, 1750: 1-18.

Haeckel, E. 1879. Das System der Medusen: Erster Theil einer Monographie der Medusen. Jena, Denkschriften Gesellschaft. 360p.

Kramp, P.L. 1948a. Medusae collected by the Swedish Antarctic Expedition, 1901-03. In: Further Zoological Results of the Swedish Antarctic Expedition 1901-1903 under the direction of Dr. Otto Nordenskjöld. Stocholm, P.A. Norstedt. v. 4: 1-16.

Kramp, P.L. 1948b. Trachymedusae and Narcomedusae from the 'Michael Sars' North Atlantic Deep-Sea Expedition 1910 with additions on Anthomedusae, Leptomedusae and Scyphomedusae. In: Report on the scientific results of the "Michael Sars" north Atlantic deep-sea expedition 1910. Bergen, Bergern Museum. v. 5, p. 1-23.

Kramp, P.L. 1955. The medusae of the tropical west coast of Africa. Atlantide Reports, 3: 239-324.

Kramp, P.L. 1957. Hydromedusae from the Discovery collections. Discovery Reports, 29: 1-128.

Kramp, P.L. 1959a. Medusae, mainly from the west coast of Africa. In: Expedition Oceanographique Belge dans le Eaux Cotières Africaines de I'Atlantic Sud. Résultats Scientific. v. 3, p. 1-33.

Kramp, P.L. 1959b. The Hydromedusae of the Atlantic Ocean and adjacent waters. Dana Report, 46: 1-283.

Kramp, P.L. 1961. Synopsis of the medusae of the world. Journal of the Marine Biological Association of the United Kingdom, 40: 7-469.

Kramp, P.L. 1965. The hydromedusae of the Pacific and Indian Oceans. Dana Report, 63: 1-162.

Kramp, P.L. 1968. The hydromedusae of the Pacific and Indian Oceans. Sections II and III. Dana Report, 72: 1-200.

Larson, R.J. 1982. Medusae (Cnidaria) from Carrie Bow Cay, Belize. Smithsonian Contributions to the Marine Sciences, 12: 253-258.

León, M.E.; Tejera, E.; Hernández, F. \& Conway, D. 2005. Medusas de las islas de Cabo Verde: resultados de la campaña TFMCBM/98 Cabo Verde. Vieraea, 33: 11-28.

Loman-Ramos, L.; Ordóñez-López, U. \& Segura-Puertas, L. 2007. Spatial variation of medusan community (Cnidaria) in the Southern Gulf of Mexico, during autumn 1999. Hidrobiologica, 17(3): 203-212. 
Lopes, R.M. 2007. Marine zooplankton studies in Brazil: a brief evaluation and perspectives. Anais da Academia Brasileira de Ciências, 79(3): 369-379.

Muñoz-Pozo, J.F. 2015. Distribución de la medusa (Cnidarios Hydrozoa) en la zona costera del puerto pesquero de Chanduy-Santa Elena, Durante el periodo de Enero-Abril 2015. B.S. thesis. Universidad Estatal Península de Santa Elena, Santa Helena.

Navas-Pereira, D. \& Vannucci, M. 1990. Antarctic Hydromedusae and water masses. Pesquisa Antártica Brasileira, 2: 101-141.

Navas-Pereira, D. \& Vannucci, M. 1991. The hydromedusae and water masses of the Indian Ocean. Boletim do Instituto Oceanográfico, 39(1): 25-60.

Oliveira, 0.M.P.; Miranda, T.P.; Araujo, E.M.; Ayón, P.; Cedeño-Posso, C.M.; Cepeda-Mercado, A.A.; Córdova, P.; Cunha, A.F.; Genzano, G.N.; Haddad, M.A.; Mianzan, H.W.; Migotto, A.E.; Miranda, L.S.; Morandini, A.C.; Nagata, R.M.; Nascimento, K.B.; Nogueira Junior, M.; Palma, S.; Quiñones, J.; Rodriguez, C.S.; Scarabino, F.; Schiariti, A.; Stampar, S.N.; Tonolone, V.B. \& Marques, A.C. 2016. Census of Cnidaria (Medusozoa) and Ctenophora from South American marine waters. Zootaxa, 4194(1): 1-256.

Osborn, D.A. 2000. Cnidaria "parasites" on Solmissus incisa, a Narcomedusa. Scientia Marina, 64: 157-163.

Pagès, F. 1992. Mesoscale coupling between planktonic cnidarian distribution and water masses during a temporal transition between active upwelling and abatement in the northern Benguela system. South African Journal of Marine Science, 12(1): 41-52.

Pagès, F.; Gili, J.-M. \& Bouillon, J. 1992. Medusae (Hydrozoa, Scyphozoa, Cubozoa) of the Benguela Current (southeastern Atlantic). Scientia Marina, 56: 1-64.

Ranson, G. 1949. Résultats scientifiques des croisières du navire-école belge "Mercator".: II-Meduses. Mémoires du Institut Royal des Sciences Naturelles de Belgique, série 2, 33: 121-158.

Repelin, R. 1965. Quelques méduses de l'île Anno Bon (golfe de Guinée). Cahiers Office de la Research Scientifique et Technique Outre-Mer Oceanograph, 3: 73-79.

Rocha, L.A. 2003. Patterns of distribution and processes of speciation in Brazilian reef fishes. Journal of Biogeography, 30(8): 1161-1171.
Rodriguez, C.S. 2012. Hidromedusas del Atlántico sudoccidental: Biodiversidad y patrones de distribución. Ph.D. Thesis. Universidad Nacional de Mar del Plata, Mar del Plata.

Schlitzer, R. 2007. Ocean Data View. Available at: https://odv.awi.de.

Schuchert, P. 2015. World Hydrozoa database. Available at: www. marinespecies.org/hydrozoa. Access in: 05/2018.

Segura-Puertas, L. 1984. Morfología, sistemática y zoogeografía de las medusas (cnidaria: hydrozoa y scyphozoa) del Pacífico tropical oriental. Mexico, UNAM. 314p. (Publicaciones especiales Instituto de Ciencias del Mar y Limnologia, 8).

Segura-Puertas, L. 1991. Medusas (Cnidaria: Hydrozoa y Scyphozoa) de la región del Domo de Costa Rica. Revista de Biología Tropical, 39(1): 159-163.

Segura-Puertas, L. 1992. Medusae (Cnidaria) from the Yucatan shelf and Mexican Caribbean. Bulletin of Marine Science, 51(3): 353-359.

Suárez-Morales, E.; Gasca, R.; Segura-Puertas, L. \& Biggs, D.C. 2002. Planktonic cnidarians in a cold-core ring in the Gulf of Mexico. Anales del Instituto de Biología Serie Zoología, 73: 19-36.

Suárez-Morales, E.; Segura-Puertas, L. \& Gasca, R. 1999. Medusan (Cnidaria) assemblages off the Caribbean coast of Mexico. Journal of Coastal Research, 15: 140-147.

Vanhöffen, E. 1912. Die craspedoten Medusen der Deutschen SüdpolarExpedition 1901-1903. In: Deutsche Südpolar-Expedition, 1901-1903. Zoologie V. Berlin, Verlag von Georg Reimer. v. 13, p. 351-395.

Vanhöffen, E. 1913. Die craspedoten Medusen des "Vettor Pisani". Zoologica, New York, 67: 1-34.

Vannucci, M. \& Navas, D. 1973. Patterns of distribution of Arabian Sea hydromedusae. In:Special Publication dedicated to Dr NK Panikkar. Kerala, Marine Biological Association of India. v. 1: 110-121.

Xu, Z. \& Wu, H. 1998. Life cycle of parasitic species of Pegantha triloba from Xiamen Harbour. Journal of Oceanography in Taiwan Strait, 17: 86-89. 